\title{
Damage to a Fiberoptic Bronchoscope due to Nasal Septal Deformity
}

\author{
Nasal Deviasyona Bağlı Fiberoptik Bronkoskop Hasarı
}

To the Editor,

A 75-year-old male patient was admitted to the clinic, and it was determined that he had a mass lesion on the left upper lob. A bronchoscopic procedure was planned for the following day in the operating room. Informed consent was obtained from the patient. Topical anesthesia of Cathejell with lidocaine 2\% (Montavit Pharmazeutische Fabrik Ges.m.b.H., Absam, Austria) was applied to the oropharynx and both nasal passages. The patient was then placed on continuous cardiac and pulse oximetry monitoring, and supplemental oxygen was applied (generally $3 \mathrm{~L} /$ minute by oral cannula), and intravenous access was established. The bronchoscope was passed through the left nostril, and was advanced past the vocal cords, trachea, and right main bronchus without any difficulty. When it was attempted to move the bronchoscope from the right lung to the left lung, friction and resistance was felt on the bronchoscope during withdrawal, but there was no resistance during forward motion. A tube of Cathejell was administered through the nose and the bronchoscope was moved backward and forward. During withdrawal, the friction continued and so lavage was performed and brush and forceps biopsies were taken. When the procedure was completed, withdrawal of the bronchoscope was intended but the friction and resistance increased. One more Cathejell tube was injected alongside the bronchoscope through the nose and the bronchoscope was moved backward and forward again. The resistance continued during withdrawal, and finally the bronchoscope was pulled out by force. There was bleeding from both the mouth and nose. On examination of the bronchoscope, surface tears due to friction were seen (Figure 1). The patient was referred to the Ear, Nose and Throat Clinic because of the bleeding in the operating room and after the necessary intervention was made, the bleeding was stopped, but the reason for this damage could not be understood. On the following day, endoscopic examination of the nose was performed by members of the Ear, Nose and Throat Clinic and in the left posterior nasal cavity, a horizontal septal spur of nasal deviation obstructing the nasal passage was determined (Figure 2).

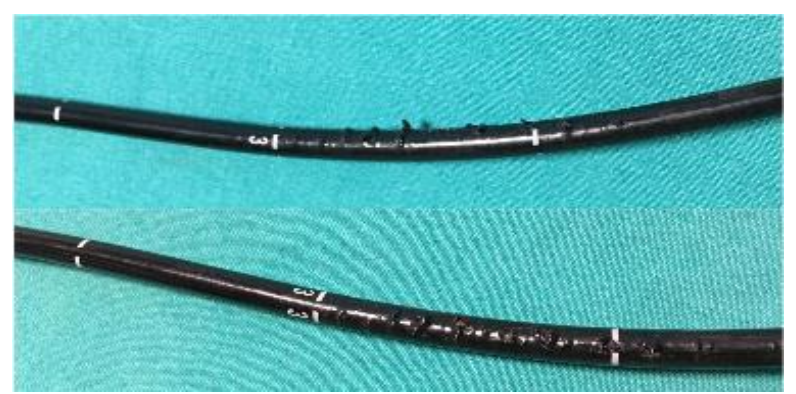

Figure 1: Surface tears on the bronchoscope

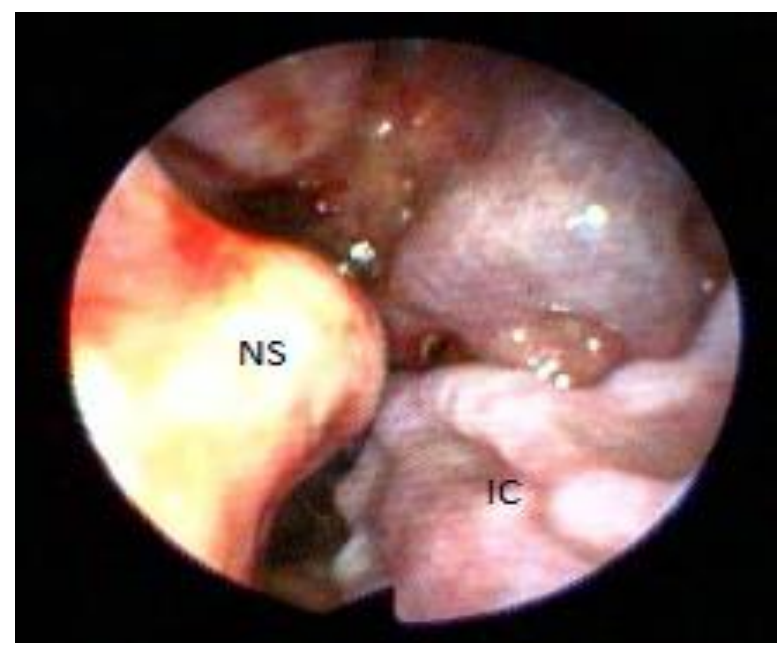

Figure 2: A horizontal nasal septal deviation obstructing the nasal passage. NS: Nasal septum; IC: Inferior concha

Flexible bronchoscopy is a safe and frequently applied technique for the assessment, diagnosis, and treatment of patients suffering from respiratory disease. The procedure has progressively improved and use has broadened since it was first used in 1968 (1). Flexible bronchoscopy is now accepted as an essential diagnostic and therapeutic instrument in pulmonary diseases (2). Following topical anesthesia 
and sedation, the flexible bronchoscope is usually inserted nasally. The oral route is an alternative; the choice depends upon individual patient characteristics (3). In this case, the nasal route was preferred. Initially, there were no difficulties in the nasal passage. However, when the bronchoscope was withdrawn, friction and resistance were felt. Interestingly, this was only a difficulty in a single direction. In this case, a left-side nasal septal deformity was found. Mladina (4) published a systematic classification of septal deformities in 1987. Nasal septum deformities were described as consisting of 6 basic types. This classification is simple, but very useful for defining septal deformities and is divided into 2 main groups: the first 4 types are vertical and the other 2 are horizontal deformities. In the current case, the nasal septal deformity on the left side was horizontal and resembled type 5 . The type 5 deformity, which is known in the literature as a "septal spur," is typically unilateral and protrudes laterally. The other side of the nasal septum is always normal. This is one of the most frequent deformities found in the general population. The incidence is low during childhood, but increases with age, and in adults, it reaches the greatest frequency (28\%). Clinically, people with this type of deformity always have impaired unilateral nasal breathing (5). Unfortunately, the current patient was not questioned about any difficulty in unilateral nasal breathing. Particularly in patients with septal deformities, nasal passage width should be carefully examined before beginning a bronchoscopic procedure. After some time, mucosal edema may increase and nasal passage narrowing may ensue, in which case, if the procedure allows for the extraction, the bronchoscopy must be extracted, or if the procedure does not allow for extraction, the removal of the bronchoscope should not be forced, but the patient should be referred to ear, nose and throat specialists to avoid damage.

\section{Hasan Kahraman', Saime Sağıroğlu², Hüseyin Arpağ', Nurhan Atilla', Fulsen Bozkuş $^{1}$}

'Department of Chest Disease, Kahramanmaraş Sütçü Imam University, Kahramanmaraş, Turkey

${ }^{2}$ Department of Ear Nose Throat Disease, Kahramanmaraş Sütçü Imam University, Kahramanmaraş, Turkey

Correspondence (iletişim): Hasan Kahraman, Department of Chest Disease, Kahramanmaraş Sütçü Imam University, Kahramanmaraş, Turkey

e-mail: drhasankahraman@hotmail.com

\section{CONFLICTS OF INTEREST}

None declared.

\section{AUTHOR CONTRIBUTIONS}

Concept - H.K., S.S., H.A., N.A., F.B.; Planning and Design - H.K., S.S., H.A., N.A., F.B.; Supervision H.K., S.S., H.A., N.A., F.B.; Funding - H.K.; Materials - H.K.; Data Collection and/or Processing - H.K.; Analysis and/or Interpretation - H.K.; Literature Review - H.K.; Writing - H.K.; Critical Review - H.K.

\section{YAZAR KATKILARI}

Fikir - H.K., S.S., H.A., N.A., F.B.; Tasarım ve Dizayn - H.K., S.S., H.A., N.A., F.B.; Denetleme - H.K., S.S. H.A., N.A., F.B.; Kaynaklar - H.K.; Malzemeler H.K.; Veri Toplama ve/veya İşleme - H.K.; Analiz ve/veya Yorum - H.K.; Literatür Taraması - H.K.; Yazıyı Yazan - H.K.; Eleştirel İnceleme - H.K.

\section{REFERENCES:}

1. https://www.uptodate.com/contents/flexiblebronchoscopy-in-adults-overview? source $=$ see link

2. Du Rand IA, Blaikley J, Booton R, Chaudhuri N, Gupta V, Khalid S, et al. British Thoracic Society guideline for diagnostic flexible bronchoscopy in adults. Thorax 2013; 68(Suppl1):i1-i44. [CrossRef]

3. https://www.uptodate.com/contents/flexiblebronchoscopy-in-adults-preparation-proceduraltechnique-and-

complications? source $=$ search result\&search $=$ bronchoscopy\&s electedTitle $=2 \sim 150 \#$ H876897868 
4. Mladina R. The role of maxillar morphology in the development of pathological septal deformities. Rhinology 1987; 25:199-205. [CrossRef]
5. Mladina R, Skitarelić N, Poje G, Šubarić M. Clinical implications of nasal septal deformities. Balkan Med J 2015; 32:137-46. [CrossRef] 